\title{
Constitutional engineering of State of exception regimes within the European Union
}

\author{
Jörg Gerkrath
}

\section{Introduction}

In a number of European state's so-called "state of emergency" or 'state of exception' or 'state of crisis' rules (hereafter generally referred to as 'State of Exception (SoE)') have been relied on in order to develop quick executive responses to the COVID-19 pandemic.

The State of exception can be defined as an extraordinary mode of governance provided for by the laws of the country and subject to such laws for their declaration and implementation. Declarations of a state of exception precede or accompany executive interventions, which could not be justified in terms of the constitution or previously established laws. ${ }^{1}$ Or, as Matthias Lemke has put it: 'In a legal sense, the term SoE refers to a multitude of different crisis reaction mechanisms that exist in the context of differentiated statehood. These mechanisms have in common that they all enhance the government's power of action and decision-making, if the relevant condition to call out a SoE are met. The declared aim of these instruments is to return as quickly as possible to the pre-crisis situation'. ${ }^{2}$

These definitions draw attention to the fact that recourse to a state of emergency regime corresponds to a certain respect for legalism, or at least the desire to demonstrate such respect and to organize the return to the normal state of legality in due time. Recent experiences of SoE declarations in Europe raise, however, the longstanding question whether emergency situations are at all amenable to constitutional or legal regulations that are meaningful and observe the principles of democracy, the protection of human rights and the rule of law.

In fact, political societies have always been confronted with this question: can the law, as an instrument of stability and social normality, 'grasp' the situation of exception and in which way? Thus, in case of imminent internal or external danger, the Roman Republic provided for recourse to the exception through the establishment of an extraordinary magistracy: the dictatorship. ${ }^{3}$

1 See International Commission of Jurists, States Of Emergency: Their Impact On Human Rights, Geneva 1983, 466 p, at p. 413.

2 Cf. Lemke Matthias, What does state of exception mean? A definitional and analytical approach, Zeitschrift für Politikwissenschaft (ZPol), 2018, pp. 373-383, at p. 374.

3 Cp. Stephane Pierré-Caps, Constitutionnaliser l'état d'urgence ?, Civitas Europa 2016, p. 141 ff, at p. 143.

1 
A first superficial comparison of the European constitutions in place reveals the existence of different models of SoE rules and regimes. The variety of names given to such regimes is in itself significant. Referring either to an emergency, a crisis, a siege, an armed attack, a state of necessity or an exceptional situation, they commonly address extraordinary and unpredictable situations which require measures that are themselves exceptional but necessary in order to react to a major threat and possibly derogatory to the constitutional standards applying in normal times.

David Dyzenhaus has rightly pointed out that, with regard to SoE rules, at least three choices have to be made within each constitutional order. ${ }^{4}$ The first is between entrenching such a regime in the written constitution and leaving it to be decided only when an emergency occurs. The second is between the 'executive model' and the 'legislative model' and the third is about the extent to which the judiciary will supervise the implementation of the SoE regime.

According to Catarina Santos Botelho such states of exception, 'are constitutional selfprotective mechanisms aimed at restoring constitutional normality'. ${ }^{5}$ Are these mechanisms, when enshrined within the Constitution itself, thus able to adjourn the normal constitutional legality? Or in other words, do they operate some kind of adjournment of constitutional rights and guarantees? This seems to be difficult to conceive if the Constitution explicitly prohibits the suspension of any constitutional provision as does for instance the Constitution of the Grand-Duchy of Luxembourg in article 113.

In the following we will follow a large definition of 'constitutional regimes', 'constitutional frameworks' and 'constitutional law'. In this large understanding, we will encompass national and supranational rules of constitutional nature or relevance as well as national and supranational legal norms that have a constitutional law significance without belonging always to the Constitution in the formal sense.

In the current European constitutional framework, often described as a multilayer constitutional system or multilevel constitutionalism, national and European rules coexist and have both to be taken into account in order to fully understand the law applying in each country. ${ }^{6}$ This is

4 David Dyzenhaus, States of Emergency in Michel Rosenfeld, András Sajó (eds.), The Oxford Handbook of Comparative Constitutional Law, OUP 2012, pp. 442-462.

5 Catarina Santos Botelho, COVID-19 and stress on fundamental rights in Portugal: An intermezzo between the state of exception and constitutional normality, Revista Catalana de Dret Públic, (special issue) 2020, 183-194. https://doi. org/10.2436/rcdp.i0.2020.3553.

6 For the original concept see Ingolf Pernice, Multilevel Constitutionalism and the Treaty of Amsterdam: European Constitution-making Revisited?, CML Rev. 1999, p. 703. 
particularly true for the 27 member states of the European Union (EU) that are bound by the law of the EU as well as by the European Convention of Human Rights (ECHR). As we will see in the following, both layers of constitutional law, the national and the European, are highly relevant when it comes to situations requiring the declaration of a SoE or the recourse to less radical extraordinary measures in order to react to an extraordinary situation as the one created by the COVID-19 pandemic.

Qualified by the German federal constitutional court (BVerfG) as a 'Verfassungsverbund', which may be translated as a composite constitutional system or a 'constitutional compound', this complex of intertwined constitutional rules contains quite a number of provisions that apply to situations wherein exceptional measures are required. To give a clear presentation of this composite legal system we will recall the different existing rules and mechanisms in evoking separately the variety of national frameworks and the relevant supranational rules.

In order to assess the choices made within this composite European constitutional system and to identify some lessons for future constitutional engineering of the SoE, we will thus summarize the variety of solutions established on the national level (I.), present the existing framework at the supranational level (I.) and discuss the critical elements of constitutional engineering in the field (III.)

\section{National frameworks of the State of exception}

As William Feldman stated in 2005, 'Any democratic government faced with a war, an invasion, a domestic insurrection, or other types of emergency must determine how it will respond. How much power will the executive be given? What will be the role of the other branches of government? How long will the response last? How will the government administer justice during such a period? What, if any, fundamental rights will be sacrificed in order to protect the nation? The way in which a nation responds to such questions will undoubtedly determine how successful it will be in responding to the crisis with which it is faced. ${ }^{7}$

The comparison of national responses to the challenge of drafting efficient SoE regimes reveals a wide variety of constitutional provisions. The different clauses have indeed been written in different contexts and with different objectives allowing the national authorities to respond to

7 William Feldman, Theories of Emergency Powers: A Comparative Analysis of American Martial Law and the French State of Siege, Cornell International Law Journal, vol. 38, no. 3, 2005, p. 1022. 
a broad range of extraordinary situations including situations of emergency, natural calamities, military aggression, occupation and others.

The scope of this limited contribution does not allow to realize a fully-fledged comparative study of the SoE regimes in all 27 EU member states. The ambition is much more modest. By discussing the genesis, the wording and the applications of the most exemplary existing regimes, based on single or multiple clauses, we will try to identify examples of good practice and models of efficient mechanisms that comply with the fundamental European principles of the rule of law, democracy and the protection of human rights.

While some member states' constitutions include indeed mechanisms allowing for recourse to a SoE or the entrustment of special powers to specific institutions, other legal orders do not, either for historic reasons or owing to institutional tradition. It seems however reasonable that the inclusion of a well-designed SoE clause within the Constitution presents a number of advantages. It adds to legal certainty and legal security, it withdraws the matter from the fluctuating will of changing parliamentary majorities and allows to define clear boundaries to the executive power in this field. In the third part, we will raise a number of questions which should be addressed by lawmakers willing to introduce or to revise the SoE clause in their constitution.

The purpose of the analysis in this first part is to assess the formal differences between the national legal frameworks on SoEs. In this context questions to be raised concern namely the legal basis of the SoE regime, which can be found in the Constitution, in ordinary legislation, in case law or in unwritten general principles of law as e.g. the principle of necessity. Furthermore, some legal orders have a unique SoE regime while others have enshrined a plurality of regimes. Finally, a classification of different SoE regimes seems to be possible to show that the different names of the thing are not always the most relevant indication. ${ }^{8}$

\section{A. The names of the thing}

The various SoE regimes are mainly designed under the names of 'State of exception' (Ausnahmezustand), 'State of necessity' (Status Necessitatis), 'Martial Law' (Kriegsrecht),

8 In the following the author relies mainly on the comparative studies realized by the Conseil d'État of Luxembourg: Conseil d'État, Avis du 15 juillet 2016 sur la proposition de revision de l'article 32 (4) de la Constitution, doc. parl. No. 6938 (4); and on behalf of the European Parliament Research service: Diaz Crego Maria, Kotanidis Silvia, States of emergency in response to the coronavirus crisis: Normative response and parliamentary oversight in EU Member States during the first wave of the pandemic, EPRS 04-12-2020, $60 \mathrm{p}$. 
'State of emergency' (état d'urgence), 'State of siege' (Belagerungszustand), 'Case of tension' (Spannungsfall), 'Case or State of defence' (Verteidigungsfall, -zustand), 'State of alert' (estado de alarma) or 'State of crisis' (état de crise).

Historically, a declaration of a 'state of siege' was the first manifestation of this phenomenon. It meant that all governmental power would be transferred to a military commander in an area under attack. Its application was a matter of custom and it remained in effect as long as a threat persisted. It was not until after the French Revolution when the state of siege was first articulated in statutory form. The French law of July 10, 1791, which established the rules governing the implementation and continuation of a state of siege, marked the beginning of its modern statutory basis. It has been constitutionalized since then and figures now in article 36 of the French Constitution where it coexists with article 16, establishing a SoE regime that doesn't bear its name. In addition, a so-called regime of 'state of emergency', was provided for in France by ordinary legislation in 1955.

In the Federal Republic of Germany, the constitution drafters of 1949 were reluctant to introduce a SoE regime because of the bad experiences made during the Weimar Republic when the emergency powers were invoked extremely often contributing to the unstable nature of the Republic. ${ }^{9}$ When it came into force, the Basic Law (Grundgesetz, GG) did not contain any provisions for the case of emergency. This has however changed since then. The introduction of the so-called 'emergency constitution' was made by the 17th Amendment Act to the Basic Law in 1968. The two central provisions of the 'emergency constitution' concern the 'case of tension' (Spannungsfall, article 80a GG) and the 'case of defence' (Verteidigungsfall, articles $115 \mathrm{a}-1151 \mathrm{GG})$, the parliamentary determination of which is the prerequisite for the applicability of a number of other provisions of the 'emergency constitution' as well as the federal emergency laws. In addition, article 91 GG provides a regime for the so-called 'domestic emergency' (innerer Notstand). This clause allows a Land to request police forces of other Länder as well as forces and facilities of other administrations and of the Federal Border Police in order to 'avert an imminent danger to the existence or the free basic democratic order of the Federation or a federate state (Land)'. So it is not true that Germany does not know a constitutional SoE regime as it is sometimes written in literature.

9 C. Jakab András, German Constitutional Law and Doctrine on State of Emergency - Paradigms and Dilemmas of a Traditional (Continental) Discourse, German Law Journal 2005, p. 453. 
These examples torn from the French and German constitutions show clearly that the generic term of 'State of exception' may refer to very different constitutional regimes. The GrandDuchy of Luxembourg still opted for a different solution and introduced a clause on the 'State of crisis' (état de crise). The recently amended article 32 (4) of the Constitution provides notably that in the event of an international crisis, a real threat to the vital interests of all or part of the population or an imminent danger resulting from serious breaches of public security, the Grand Duke, having ascertained the urgency resulting from the impossibility of the Chamber of Deputies to legislate within the appropriate time limits, may take regulatory measures in all matters'.

Not a single EU member state has provided for something like a "State of health emergency" on the constitutional level. In Spain, however, the Organic Law 4/1981 of 1 June 1981 on states of alert, exception and siege, as foreseen by article 116 of the Constitution, provides, inter alia, for the declaration of a state of alert in the event of health crises, such as epidemics and serious cases of pollution (Article $4 \mathrm{~b}$ ).

France also inaugurated some kind of "State of health emergency" legal regime in 2020. Article L 3131-12 of the Code of Public Health thus permits the declaration of a public health emergency. It differs from the 'ordinary' state of emergency provided for by Act No. 55-385 of 3 April 1955 (serious breaches of public order and public calamity) mainly in that the declaration of a state of public health emergency concerns only the case of 'a public health disaster which, by its nature and gravity, endangers the health of the population'. In both cases, infringements of civil liberties are possible.

\section{B. The Legal Basis of a SoE Regime}

The vast majority of EU member states' legal orders define one or several SoE regimes on the level of their Constitution. Only three out of the twenty-seven Member States do not provide for any sort of SoE clause at all (Austria, Belgium and Denmark). The latter provide, however, for alternative ways to react, allowing exceptional transfer of legislative powers to the monarch i.e. the executive (Belgium and Denmark), or to the Federal President (Austria).

Seventeen Member States even know a comprehensive constitutional emergency clause suitable to respond to a pandemic. Based on experiences of the first wave of the COVID-19 pandemic, a very thorough research study of the European Parliament identified four main normative responses, as there are: constitutional states of emergency, statutory regimes, the use 
of special legislative powers by the executive and, finally, the exclusive recourse to ordinary legislation. ${ }^{10}$

It is difficult to assess if one or the other of these different types of normative frameworks is better adapted to deal with an emergency situation like the one created by the COVID-19 pandemic. From a point of view of legal certainty, of predictability and the protection of constitutional values as well as human rights and freedoms, it seems, however, preferable to opt for a single and comprehensive constitutional clause that is applicable to any case of emergency or state of exception.

\section{Archetypes of SoEs}

Matthias Lemke divides SoE regimes into three types: first, an 'extralegal', second a 'legally integrated and executive oriented' and, third, a 'legally integrated and non-executive orientated' arrangement. According to him a SoE is 'extralegal if its proclamation suspends the constitution for the duration of the SoE'. It is 'legally integrated if the constitution is only partially suspended during the application of the SoE'. ${ }^{11}$

The different types of constitutional provisions on SoEs tend to respond to the various risks that can potentially threaten the existence of a state, its constitutional order or its population. From a systematic perspective, the most frequent constitutional threats that have been observed as a source of a state of emergency in the EU can be grouped into three main categories: i) external threat in the form of war (also often referred to as state of siege); ii) internal threat consisting of situations that endanger the democratic endurance of the state function, insurrection or internal state of tension; and iii) external natural events, such as natural disasters, catastrophes. Some constitutions have established a graduated response to emergencies. In this case the choice of one of the available SoE regimes will have to be made according to the principle of proportionality and after a thorough analysis of the nature and the gravity of the internal or external threat. According to the adage 'who can do more, can do less', it does not seem indispensable to have different levels of SoE foreseen by the constitution.

10 See Diaz Crego Maria, Kotanidis Silvia, States of emergency in response to the coronavirus crisis: Normative response and parliamentary oversight in EU Member States during the first wave of the pandemic, op. cit.

11 Lemke Matthias, What does state of exception mean? A definitional and analytical approach, Zeitschrift für Politikwissenschaft (ZPol), 2018, p. 374. 


\section{Unicity or Plurality of SoEs}

Several member states' constitutions entail several regimes SoE which can be chosen according to the nature and/or the gravity or the nature of the threat. Thus, the French Constitution refers in article 16 to a sort of SoE defined by the existence of 'a serious and immediate threat to the institutions of the Republic, the independence of the Nation, the integrity of its territory or the fulfilment of its international commitments'. It furthermore adds the criterion of an interruption of the regular functioning of the constitutional organs. It also provides, in Article 36, for the proclamation of a 'state of siege', without providing the slightest clarification. A constitutional amendment initiated at the end of 2015 and abandoned in March 2016, aimed to add an article 36-1 containing a reference to the 'state of emergency' currently foreseen by ordinary legislation. The Spanish Constitution enshrines in Article 116 the concepts of 'state of alert' (estado de alarma), 'state of exception' (estado de excepción) and 'state of siege' (estado de sitio), which correspond to different scenarios of emergencies. A similar though more differentiated solution is to be found in the German Grundgesetz, already mentioned.

Other member states, as Luxembourg, have drafted single SoE clauses that are meant to apply to any type of crisis. From the point of view of constitutional engineering, this choice presents the advantage of simplicity and transparency in the eyes of the citizens. It also circumvents any risk of political dispute about the best suited clause to apply in a given emergency situation.

Although this short study does not allow to identify the existence of a European standard of SoE clauses, the next developments will show that the influence of supranational European law provides for some common rules and constraints in this field.

\section{Supranational legal rules}

On the European supranational level, the main relevant rules that may interfere with national decisions, having recourse to constitutional clauses on SoE, are to be found within the European Convention on Human Rights (ECHR) (1.) and the EU legal order (2.) Both provide at least for a monitoring of the national decisions.

\section{A. The European Convention on Human Rights}

As many other universal and regional international human rights treaties, the ECHR provides for a mechanism allowing its contracting parties to derogate from the normal standard of protection of the conventional rights or to suspend their application. This clause for 'derogation 
in time of emergency' figures in article 15 ECHR. It applies 'in time of war or other public emergency threatening the life of the nation' and empowers the states to take measures derogating from their conventional obligations. Only measures 'strictly required by the exigencies of the situation' are, however, allowed and they must be consistent with the contracting state's other duties under international law. Derogations from Article 2, except in respect of deaths resulting from lawful acts of war, or from articles 3, 4 (paragraph 1) and 7 are excluded. Derogatory measures taken and the reasons therefore as well as the decision to end them returning to the full respect of the Convention them are to be notified to the Secretary General of the Council of Europe.

During the COVID-19 pandemic, ten out of forty-seven Council of Europe (CoE) members made notifications under article 15 ECHR. ${ }^{12}$ Among those ten there were only three EU member states: Latvia, Estonia and Romania. Estonia ended its emergency situation and withdrew its notification under article 15 ECHR from March 2020 on May 18, 2020. The notification of derogation issued by Romania in March 2020 was withdrawn on May 15, 2020. Currently, in January 2021, only Latvia has a derogation notification in place dating from December 31, 2020.

The regime set up by article 15 ECHR fully corresponds to what David Dyzenhaus called the 'the derogation model'. ${ }^{13}$ This model intends to integrate the imperative of efficiency of the executive response to the emergency situation. It does, however, also provide, in a second time, for the imperative of legality to be respected. This is reached through the judicial review of the European Court of Human Rights (ECtHR) or other international bodies. A more or less intensive international control on the implementation of the contracting states' right to derogate isn't indeed irreconcilable with the specific requirements of an emergency situation. ${ }^{14}$

The judicial review by the ECtHR follows three patterns: it excludes any control of the appropriateness of the state's decision to exercise the right to derogate, it comprises, however, a strict monitoring of the respect of the formal and material conditions of the derogation

12 See the list (up to date until January 4, 2021) on the CoE website, https:/www.coe.int/en/web/conventions/fulllist/-/conventions/webContent/62111354, accessed on 28.1.2021.

13 Cf. David Dyzenhaus, States of emergency, in Michel Rosenfeld/Andras Sajo (eds.), The Oxford Handbook on Comparative Constitutional Law, Oxford 2012, at p. 451. See also Tom R. Hickman, Between Human Rights and the Rule of Law: Indefinite Detention and the Derogation Model of Constitutionalism, Modern Law Review, 2005, pp. 655-668

14 See in this sense Ludovic Hennebel, Hélène Tigroudja, Traité de droit international des Droits de l'Homme, Paris, Pedone 2016, at p. 719 ff. 
declaration or notification. This entails a judicial control of the adequacy of the derogatory measures in the light of the declaration of an emergency as well as their necessity and proportionality. ${ }^{15}$

\section{B. Declaration of SoE and the EU Legal Order}

The EU legal order does not contain any general rule considering explicitly the declaration of SoEs by its member states. There are, however, a number of provisions and principles that have to be respected by the member states in such an event or may apply in order to organize a joint reaction. The main relevant principles and rules that may come into play during a SoE in one or several member states result from what is known under EU law as the 'mutual defence clause', the 'solidarity clause', the 'duty of sincere cooperation' and the 'public order, public security and public health exception'.

The Treaty of Lisbon, which is in effect since December 1, 2009, strengthened the unity of the EU members in dealing with external threats by introducing a mutual defence clause in article 42(7) TEU. This clause postulates that if a member state is the victim of armed aggression on its territory, the other EU countries have an obligation to aid and assist it by all the means in their power, in accordance with article 51 of the United Nations Charter. This obligation of mutual defence is binding on all member states. However, it does not affect their possible neutrality and is consistent with their commitments as NATO members.

The solidarity clause, codified in article 222 TFEU, also by the Lisbon Treaty, provides that EU members are obliged to act jointly where one of them is the victim of a terrorist attack or a natural or man-made disaster. The clause was conceived in the following of the terrorist attacks in Madrid in March 2004. In 2014, the EU adopted a decision to lay down the rules and procedures for the operation of the solidarity clause. It ensures that all the parties concerned at the national and at EU level work together to respond quickly, effectively and consistently in the event of terrorist attacks or natural or man-made disasters. ${ }^{16}$

The duty of sincere or loyal cooperation, laid down in article 4(3) TEU, embraces a mutual legal obligation for the EU institutions and the Member States, 'to assist each other in carrying

15 Cp. notably ECtHR, Ireland v. United Kingdom, 18 January 1978, application no. 5310/71, § 163 and ECtHR, Öcala v. Turkey, 12 May 2005, application no. 46221/99, §179.

16 2014/415/EU, Council Decision of 24 June 2014 on the arrangements for the implementation by the Union of the solidarity clause, EUOJ L 192, 1.7.2014, p. 53. 
out the tasks which flow from the Treaties'. This general obligation is part of what is considered under EU law as the specific status of the member states, sometimes referred to as a status of 'integrated states'. ${ }^{17}$ It applies generally and certainly also during an emergency or exceptional situation affecting one or several member states. It would at least require member states willing to adopt derogatory measures to consult with the EU institutions and the other member states before put in place measures such as unilateral border controls for instance.

The so-called 'public order (or public policy), public security and public health' exception is enshrined within the EU founding treaties, mainly in the field of free movement by article 52 TFEU, as well as in secondary law. ${ }^{18}$ It does not, however, give a 'carte blanche' to the member states. Rather to the contrary. Member states are closely controlled in the use they make of their public policy. ECJ case law and secondary law have indeed, not only defined the content of what might constitute a member state's public order concern, but also its concrete process of application. ${ }^{19}$

Regarding for instance the operation of border controls within the 'Schengen Area', defined as an area without internal borders controls, the EU Borders Code, also known as 'Schengen Borders Code', a regulation from 2016, imposes strict conditions on member states desiring to reintroduce such controls at the internal borders of the EU.

The ECJ has had occasion to state that 'article 25 of the Schengen Borders Code allows, exceptionally and under certain conditions, a Member State to reintroduce temporarily border control at all or specific parts of its internal borders where there is a serious threat to public policy or internal security in that Member State' ${ }^{20}$ It can be assumed that the notion of public order can include that of public health. Other texts of Union law thus refer typically to the triptych of public order, public safety and public health. ${ }^{21}$

17 See Jörg Gerkrath, The Figure of Constitutional Law of the 'Integrated State': The Case of the Grand Duchy of Luxembourg, EuConst 2014, p. 109.

18 Notably in articles 27 -33 of Directive 2004/38/EC of the European Parliament and of the Council of 29 April 2004 on the right of citizens of the Union and their family members to move and reside freely within the territory of the Member States, EUOJ, L 158, 30.04.2004, p. 77.

19 Cf. amongst many contributions Catherine Kessedjian, Public Order in European Law, Erasmus Law Review, 2007, pp. 25-36.

20 ECJ,19 March 2019, Préfet des Pyrénées-Orientales v Abdelaziz Arib, C-444/17, ECLI:EU:C:2019:220, point 49.

21 Regulation (EU) 2016/399 of the European Parliament and of the Council of 9 March 2016 on a Union Code on the rules governing the movement of persons across borders (Schengen Borders Code), OJEU, L 77, 23.3.2016, pp. $1-52$ 
According to settled case law, recourse to the concept of public policy presupposes, however, in any event the existence of 'a real, present and sufficiently serious threat to affect one of the fundamental interests of society' (recital 27 of the Borders Code). Articles 27 to 31 of Directive 2004/38 on the free movement of citizens of the European Union codifies the material conditions that Member States have to respect when they want to take restrictive measures that affect the free movement of EU citizens while being justified by threats to public policy, public security or public health.

\section{Critical components of SoE regimes in Europe}

Within the third part of this contribution, we will focus on the main elements of SoE regimes. Crucial aspects of the exercise of public powers under those regimes include not only the extent of the measures adopted, but also their legitimacy, raising the question of their initiation, their duration and of the degree of parliamentary oversight and judicial review. Comparative studies conducted on the recourse to SoE regimes during the first wave of the COVID-19 pandemic show a broad variety of rules and practices. ${ }^{22}$

\section{A. Initiation}

Regarding the initiation of a SoE mechanism many questions have to be solved. According to the political system in place, the Constitution will usually recognize this power to the executive branch, the head of state or the head of government. Some constitutions require the executive to hold a prior consultation with the constitutional court (France) or to obtain a favourable vote in Parliament (Germany). Such requirements are to be welcomed as they tend to limit the risk of a purely executive driven response.

In many cases there will be no difficulty to determine the existence of a serious threat to the national or the constitutional order. In others, like the current threat generated by the COVID19 pandemic, scientific expertise might be necessary in order to evaluate the seriousness of the threat and the necessity to react by the declaration of a SoE. This raises the question who really declares the SoE and based on which evidence. Is it up to the scientific community or do we

22 Cf. the rich study of Maria Diaz Crego and Silvia Kotanidis, States of emergency in response to the coronavirus crisis: Normative response and parliamentary oversight in EU Member States during the first wave of the pandemic, (EPRS) European Parliamentary Research Service, 04.12. 2020, 60 p; see also Conseil d'Etat (Luxembourg), opinion of 15.7. 2016, doc. parl. $\mathrm{n}^{\circ}$ 6938(4), pp. 3-7; and 
need to defend the classical politic primacy in this field? The link between science and the law becomes particularly evident.

In fact, there are strong similarities in this field to matters addressed by environmental and climate change law. It seems for instance highly relevant to apply the precautionary principle when making the proportionality test of measures taken during a SoE meant to tackle a pandemic. In both situations there is a strong connection to scientific expertise and a vital need of the political institutions to receive impartial scientific advice. The question how to organize the availability of such advice for the decision makers is of course central. It should not be overinstitutionalized, and it should be made sure that all independent sources of scientific expertise are available to the constitutional organs.

Many events or circumstances may lead to the declaration of the SoE. It is difficult in terms of constitutional engineering to foresee all of them. The threats can have different origins, external or internal, political or military, natural or man-made. The SoE clause should tend to define these circumstances in a comprehensive manner without being too vague. Bearing in mind that only 17 EU member states know SoE clauses that are suitable to apply to a pandemic, there is certainly a gap to be filled.

The SoE clause should also take into account that the seriousness of a threat also depends on the potential victims of the threat. The subjects that deserve to be protected by the exceptional measures to be taken should indeed be identified. The liberal and democratic constitutional order, the nation, the population, the democratically legitimized institutions are certainly possible subjects to be mentioned in order to define the seriousness of an emergency situation. A menace for an individual head of the state or for a specific political party in power is certainly not sufficient to declare the SoE.

We should also bear in mind that achievements realized on the European level should not be torn aside to easily. During situations that give rise to the declaration of SoEs national Sonderwege may lead to reinforce nationalistic tendencies that we thought we had overcome within the European Union. The unilateral re-instauration of border controls at the internal borders of the Union should thus be strictly monitored by the EU Commission and the conditions that are laid down in the Schengen Borders Code need to be respected, even in times of a pandemic.

As the conditions to be respected when switching from the ordinary 'state of constitution' to the 'state of emergency' are manifold, it is particularly important to decide who monitors whether these conditions are fulfilled. Safeguards against any kind of abuse are crucial in order 13 
to avoid that the state of exception becomes the normal situation. Such safeguards can result from different mechanisms as we will see in the following

\section{B. cooperation of powers and parliamentary oversight.}

Regardless of the importance of the principle of separation of powers within the constitutional regimes of all EU member states, during an emergency or exceptional situation it is vital to organize a fruitful cooperation between the three branches of sovereign powers.

The common feature of SoE regimes is to grant extraordinary powers to the (central) executive in order to allow a rapid and efficient reaction. Mainly this includes the transfer of legislative powers to the executive. The executive organs have indeed traditionally been considered better suited to deal with crises than legislatures, due to their hierarchical structure, their ability to respond more speedily and flexibly to immediate challenges and their better access to expertize. This pattern is certainly core to any SoE regime. It should, however, not exclude the two other branches of government from exercising their constitutional role during the implementation of the extraordinary measures. A SoE regime that is consistent with the common European values of democracy, the rule of law and the protection of human rights that are enshrined within the status of the Council of Europe as well as in the Treaty on the European union, must uphold these values as far as possible also in times of emergency.

More precisely this leads to the requirement of a close cooperation of the three branches of powers and to the need to organize an efficient way to allow parliamentary oversight on the different stages of an implementation of a SoE. This oversight should be arranged from the declaration itself until the termination of the SoE.

The experience made within the Grand-Duchy of Luxembourg is, again, inspiring in this regard. When, in June 2020, the SoE ended after 3 months and Parliament regained its full rights, the statement of its President Fernand Etgen was clear: 'This delegation of powers was not a blank cheque for the government,' he explained during the last public session in 2020. 'I am proud to note that the Chamber has worked closely with the government and the Council of State in an exemplary and supportive manner, while at the same time remaining critical'. 'The Chamber has fully carried out its legislative and oversight duties', he added. Eighteen meetings at the highest level of elected representatives with members of the government were organised to provide weekly updates on the management and development of the pandemic in Luxembourg. The chamber held altogether 21 public sessions and 189 meetings in parliamentary committees 
and, unlike many parliaments abroad, the Chamber remained thus fully operational throughout the state of emergency. The deputies have voted about 60 bills in the three months of the 'state of crisis', including the 'covid statutes' which provide the rules of conduct to continue the fight against the virus. Twenty-one public sessions have been organised.

\section{Duration}

The declaration of a SoE must be limited in time. The shorter the better. Prolongations must, of course, be envisaged but should be limited in number and in duration in order to prevent the occurrence of the famous 'permanent situation of emergency' discussed by Giorgio Agamben. Article 32 (4) of the Constitution of Luxembourg seems to be a good example. It allows declaring the 'State of crisis' for an initial duration of ten days. Any prolongation going beyond these ten days needs to be approved by parliament (Chambre des deputes) voting with a twothirds majority and cannot go beyond three months in any case.

As the genuine aspiration of any SoE or state of emergency law should be to secure the route back to the 'normal' constitutional state, a precise rule about the termination of the SoE undeniably has to be included in a SoE constitutional clause.

\section{The scope of the derogatory measures and their effects of fundamental rights and freedoms}

A declaration of a SoE will usually be followed by the adoption of executive measures that may derogate from ordinary legislation during a certain lapse of time. Under the European constitutional model, it is not conceivable any more that the SoE leads to the suspension of ordinary legality or even to the suspension of constitutional norms.

According to the derogation model, the SoE constitutes rather a limited derogation from the ordinary legality including the limited possibility to derogate from constitutional or conventional human rights.

As article 15 of the ECHR, article 4 of the International Covenant on Civil and Political Rights recognizes hence also the right of governments 'in time of public emergency which threatens the life of the nation' to derogate, with certain exceptions, from their obligations under the Covenant, 'to the extent strictly required by the exigencies of the situation'.

This is also consistent with the positive obligation of the state to protect the right to live and the right for corporal integrity against health risks of the individuals. During a SoE, which derives 
from a pandemic or another threat to life or the public health, the need to ensure a protection of the most vulnerable (elder persons, children, prisoners, refugees, detained or hospitalized persons, ...) weighs heavily in the proportionality test to be made. Thus other fundamental rights may be limited as far as it is necessary.

Also, the enjoyment of fundamental rights and freedoms engenders human duties, even though the latter are rarely explicitly named. It is, however, reasonable to conceive a human duty to contribute to the public measures taken against the spreading of the Corona Virus in order to protect the fife of others. Such a duty stems logically from the adage that 'one's personal freedom ends where the personal freedom of another begins'. This might then be understood as a supplementary justification for the need of (proportionate) restrictions to some fundamental rights as personal data protection, free movement, free speech and freedom of assembly. Their proportionality has to be assessed in the light of the precautionary principle and may thus be easier accepted than usually.

When it comes, however, to very intrusive executive measures that limit the personal freedom in an extreme manner as for instance measures imposing compulsory quarantine or forced hospitalization, the proportionality test should be very rigorous. This leads us naturally to the role of a judicial review during the application of a SoE regime.

\section{E. Judicial Review}

At first sight judicial review seems to be somewhat contradictory to the very nature of a SoE regime. The latter is designed to allow a prompt response to an imminent threat and the functioning of justice requires time. So, one might consider that the judicial control will normally take place only at a later stage and will be limited in order to respect the wide margin of appreciation that the SoE regime usually recognizes to the executive.

A first fascinating option is to provide for an action against the very decision of the executive to declare the SoE. Why shouldn't there be an action open for instance to the minority in parliament or to a certain number of representatives to refer the question to the constitutional court through some kind of urgency procedure. It would be up to this court to decide at least at first sight if the conditions for the declaration of a SoE have been met.

During a regime SoE the legality and the constitutionality of the executive measures should also be subject to ordinary judicial review. There should be no place for 'judicial self-restraint' 
in this field neither from the ordinary judges nor from the constitutional judges. ${ }^{23}$ At the contrary the Constitution should underling the full applicability of constitutional rules on effective judicial protection in times of SoE.

The intensity of judicial review will naturally be limited. A certain margin of appreciation has to be recognized to the executive. But an intensive judicial control can always be realized $a$ posteriori and also on the supranational level. It would be crucial in order to deliver an authoritative interpretation of the SoE clause and the different conditions laid down therein.

\section{Conclusion}

The question of how to draft an excellent SoE regime is not easy to answer. Many aspects have to be taken into account. The main guidelines which should be followed by drafters of constitutional SoE regimes are still very clear. The objective must be to allow an efficient and rapid government action in order to respond to an unpredictable situation of emergency or crisis. This implies in practice a stronger role of the executive than in ordinary times. At the same time the rules that allow this executive response must also safeguard the main values of European constitutionalism: the rule of law, the protection of the fundamental rights of the individual as well as the separation - or better cooperation - of powers and democracy. The task is not an easy one. The experiences made during the COVID pandemic might, however, help to draft such SoE regime clauses that will allow us to tackle the threats resulting inter alia from climate change in the coming years. 
Literature :

- Ackerman Bruce, The Emergency Constitution, The Yale Law Journal 113 (2004), p. $1029 \mathrm{ff}$.

- Agamben Giorgio, State of Exception, University of Chicago Press 2005, 111 p.

- Diaz Crego Maria, Kotanidis Silvia, States of emergency in response to the coronavirus crisis: Normative response and parliamentary oversight in EU Member States during the first wave of the pandemic, EPRS | European Parliamentary Research Service, 0412-2020, $60 \mathrm{p}$.

- Dyzenhaus David, States of Emergency, in Michel Rosenfeld, Andras Sajo (eds.), The Oxford Handbook on Comparative Constitutional Law, Oxford 2012, p. 442 ff.

- Dyzenhaus David, L'état d'exception, in M. Troper, D. Chagnollaud (eds.), Traité international de droit constitutionnel, T. II, Distribution des pouvoirs, p. $739 \mathrm{ff}$.

- Fraenkel Ernst, The Dual State: A Contribution to the Theory of Dictatorship, (orig. in German 1943), The Lawbook Exchange, Ltd., Reprint 2010, 266 p.

- Feldman William, Theories of Emergency Powers: A Comparative Analysis of American Martial Law and the French State of Siege, Cornell International Law Journal, vol. 38, no. 3, 2005, pp. 1021-1048

- Greene Alan, Permanent States of Emergency and the Rule of Law. Constitutions in an Age of Crisis, Hart Publishing, Oxford 2018, 256 p.

- Gross Oren, Law in Times of Crisis. Emergency Powers in Theory and Practice, 2006

- Grote Rainer, Regulating the State of Emergency - The German Example, Israel Yearbook on Human Rights, 2003, p. 151 ff.

- International Commission of Jurists, States Of Emergency: Their Impact On Human Rights, Geneva 1983, 466 p.

- Jakab András, German Constitutional Law and Doctrine on State of Emergency Paradigms and Dilemmas of a Traditional (Continental) Discourse, German Law Journal 2005, p. 453.

- Lemke Matthias, What does state of exception mean? A definitional and analytical approach, Zeitschrift für Politikwissenschaft (ZPol), 2018, pp. 373-383.

- Rossiter Clinton, Constitutional Dictatorship. Crisis Government in the Modern Democracies, New Brunswick und London 2002 (1948) 